UNIVERSITY OF WORCESTER

\title{
The changing nature of Sino-foreign business relationships, 1842-1941
}

\section{Howard Cox and Kai Yiu Chan 2000}

This is an electronic version of a paper that was published in Asia Pacific Business Review, Vol.7, No.2, (2000), pp.93-110. 


\begin{abstract}
$\underline{\text { Abstract }}$
During the second half of the nineteenth century, foreign business enterprises relied considerably upon the service of compradors to extend their economic interests in the Chinese economy. Utilised initially to overcome the barriers presented by language difficulties, compradors were employed by western firms to undertake a variety of tasks covering both supervisory and co-ordination functions. With the growth of industrial interest by foreign businesses during the twentieth century, however, the comprador system fell into disrepute and during the 1930s was largely abandoned.This paper employs research based on primary source materials to trace this institutional transition for two specific cases. The Kailan Mining Administration (KMA), whose origins are to be found as an Anglo-Belgian free-standing company, took control of both the Kaiping and Lanchow coal mines in 1912. In order to expand its sales, the company employed the services of the comprador Liu Hongsheng who successfully built up the company's market around Shanghai. In doing so, however, Liu became an important force in coal distribution in his own right, leading to tensions that were resolved through the creation of a joint venture operation called the Kailan Sales Administration (KSA) in 1925.British-American Tobacco (BAT) was set up in 1902 to administer the foreign markets of the American Tobacco Company and Britain's Imperial Tobacco Company. In China, a distribution system was created using many Chinese collaborators of whom two were of particular importance. Wu Ting Seng, a member of the Chinese gentry, played a crucial intermediating role for the western company in a variety of its dealings with the Chinese. Cheang Park Chew, on the other hand, was an influential Cantonese merchant whom BAT used to distribute its goods throughout the Shanghai region. In both cases, BAT chose to alter the institutional arrangements with these collaborators from the contractual form to joint venture partnerships, unsuccessfully in the case of $\mathrm{Wu}$, but with phenomenal success in the case of Cheang's mercantile enterprise, the Wing Tai Vo Tobacco Corporation.
\end{abstract}


The changing nature of Sino-foreign business relationships, 1842-1941

\section{Howard Cox and Kai Yiu Chan}

From the onset of the Treaty Port era until the Republican revolution of 1911, the key actor linking foreign business enterprises with the mainstream Chinese economy was the comprador. To date, however, the degree of detailed historical analysis given to the rise and, more particularly, to the decline of this institution of economic intermediation has been extremely limited. The most complete English language treatment of the comprador remains the study by Hao (1970). This work was based primarily on the records of three large western trading companies - Russell \& Co., Augustine Heard \& Co. and Jardine, Matheson \& Co. - and was limited to the period up to 1890 . Hao's study thus devotes very little attention indeed to the question of the decline of the compradoric system during the twentieth century. And although two particularly important non-English language accounts of the comprador system (Negishi, 1948; Wang, 1990) both identify the emergence of variant forms of Sinoforeign economic intermediation to the comprador after 1900, the studies provide little by way of economic and historical analysis through which the mechanisms driving the process of institutional evolution may be assessed.

In fact, it is clear that the declining role of the comprador as a trading intermediary mirrors the diminishing importance of western firms in managing China's import and export trade more generally. As Osterhammel (1999b: 653-4) has pointed out, the period from 1842 to 1895 represents the high-water mark of Treaty Port trade and by the final decade of the nineteenth century this form of foreign involvement in 
the Chinese economy had largely given way to an era of high finance which lasted until the outbreak of the First World War in 1914. During this latter period, it is evident that the most important role performed by compradors was to act as financial intermediaries, operating especially between the western banks and their native Chinese counterparts.

In Osterhammel's schema, the era of high finance rapidly collapsed following the political turmoil of the Republican revolution and its immediate aftermath, as well as being a consequence of the dislocations engendered by the First World War. He suggests that the inter-war years were characterised primarily as a period of market penetration during which a small number of relatively large foreign firms attempted to secure widespread sales for their products using distribution mechanisms which extended deep into the Chinese economy. Among British representatives of this group of firms are the British-American Tobacco Co. (BAT) and the Kailan Mining Administration (KMA), both of whom engaged also in local production, and Imperial Chemical Industries (ICI) and the Asiatic Petroleum Co. (APC) who distributed products transferred from their plants abroad.

The identification of these three epochs of foreign involvement in the Chinese economy between 1842 and 1941 enables the rise and decline of the comprador to be placed in a broad historical perspective. However, the purpose of the present paper is to go beyond this purely historical framework in order to analyse the shortcomings of the institutional arrangements that underpinned the compradoric system from an economic perspective. In particular, it seeks to assess the organisational arrangements that foreign firms introduced between the two world wars to help alleviate the problems that foreign business enterprises had encountered in their earlier dealings 
with Chinese intermediaries. Thus the main purpose of the present paper is to consider the way in which firms such as BAT and KMA successfully engaged domestic firms in the distribution of their products within China and to explore the nature of economic intermediation that such a strategy necessitated. In effect, our objective is to analyse the economic arrangements that foreign firms developed as they sought to establish alternative means of intermediation between themselves and the wider Chinese economy that lay beyond the Treaty Ports.

The paper begins by outlining the various roles performed by compradors on behalf of foreign firms in the period before 1911. Whilst the evidence illustrates that there was a diverse set of functions that were delegated by foreign firms to their compradors, the essential institutional arrangement is found in section two of the paper to reside in various combinations of an employee/agent dichotomy that served to characterise the economic relationship between the western enterprise and its Chinese intermediary. The paper then moves on to undertake two case studies of firms that, during the Republican period, successfully developed distribution systems for their products using networks of Chinese merchants. Analysis of the cases of BAT and KMA both illustrate the ability of foreign firms to recast their relations with Chinese intermediaries in a way that enabled the earlier difficulties inherent in the employee/agent form of relationship to be successfully overcome. Such developments were predicated on the introduction of western-style institutional structures of parent/subsidiary companies, facilitated by the granting of limited liability to companies in China's first Company Law of 1904 (Kirby, 1995: 43). These parent/subsidiary relations enabled foreign firms to gain access via the Chinese intermediaries to indigenous networks of distribution whilst, at the same time, facilitating much more 
effective systems of monitoring and supervision than the earlier employee/agent type of arrangement had permitted.

Compradors and Economic Intermediation

Before 1842, all maritime trade between foreigners and the Chinese economy was mediated through the operation of the 'Canton (Guangzhou) system' under which a guild of merchants, the Cohong (Gonghang), were given responsibility for western ships as they berthed at China's sole coastal trading port. These merchants were appointed by the Imperial Qing government as exclusive brokers for China's maritime trade and were supervised by the Emperor's Superintendent of Maritime Customs for the Guangdong region. Following the signing of the Treaty of Nanjing in 1842, China embarked upon a century during which its international economic transactions were conducted through the Treaty Port system featuring the legal device of extraterritoriality (foreign consular jurisdiction over foreign nationals) (Fairbank, 1992: 195-205). With the introduction of Treaty Ports as designated locations for foreign trade, the formal arrangements of the Cohong were brought to an end and the era of the comprador had arrived.

As Cain and Hopkins (1993: 426) point out, the Treaty Ports were designed to provide Western mercantile interests, spearheaded by Jardine, Matheson and Co., with a bridgehead into the potentially vast Chinese market for cotton piece goods and other commodities. To cross this bridge, however, western traders required the support of Chinese natives to act as trade emissaries on their behalf. During the early phase of Treaty Port consolidation, the group of around 250 Chinese merchants who performed 
this role became known as compradors, a term derived from the Portuguese word 'compradore' that was applied to the Chinese servants of foreign merchants in Canton and Macao who procured provisions from the mainland on behalf of their masters under the Cohong system. As the western agency houses set up their operations directly within the Treaty Ports, a comprador was appointed in the capacity of house steward. This "house comprador" would be given responsibilities for the procurement of day-to-day necessities and for the management of the various Chinese staff (shroffs, caterers and others) whose services were required for the successful running of the enterprise. The office of the comprador thus emerged as a "firm within a firm", in which the comprador rather than the foreign principal commanded the Chinese staff (Hao: 1970).

These house compradors of the foreign merchants were originally appointed on the basis of trust and reputation. From the 1850s, however, appointment of new compradors was usually dependent upon a financial guarantee pledged by an existing comprador (McElderry, 1995: 35-6). This system of pledges created interlocking groups of compradors connected by place of origin and, by such means, the group of Cantonese merchants who had operated the Cohong system were able to maintain a position of pre-eminence amongst the network of compradors serving foreign merchants until the 1870s. After this time, particularly following the emergence of Shanghai as the leading Chinese Treaty Port, the Cantonese merchants faced increasing competition from groups originating from Jiangsu and Zhejiang (Bergère, 1986: 40).

The ending of the Cohong system, as well as enabling foreign merchants to establish offices within the Treaty Ports, also allowed these trading firms to extend their influence into the Chinese economy proper. Those export merchants with 
sufficient capital resources at their disposal, such as Jardine, Matheson, began to find it expedient to use trusted Chinese intermediaries to obtain their requirements of tea and silk directly from the upcountry suppliers. Such an approach involved furnishing Chinese agents with substantial sums of money (or other forms of exchange such as opium) and allowing them to transact directly with the Chinese commercial networks beyond the Treaty Ports through which these commodities passed. In contrast to the house steward function, therefore, this role of upcountry purchasing created a more peripatetic form of compradorship in which the comprador himself acted essentially in the capacity of an agent rather than that of an employee.

The success of the policy depended upon the trustworthiness of those agents who performed the task and it thus drew upon the mechanisms of interlocking guarantees and collegiate trust that characterised the comprador system as a whole. However, upcountry purchasing provided compradors with tremendous scope for exacting squeeze and engaging in own-account trading. As the nineteenth century wore on, the ability of the Chinese compradors engaged in such activities to exploit their position as intermediators allowed them to exert a decisive influence over Chinese trade networks, extending their activities into the grading, sorting and preliminary processing of materials for export. As their wealth accumulated, many of these compradors terminated their direct relationship with the agency houses but continued to act on their behalf as commission agents. Moreover, by virtue of their connections to the upcountry commercial networks, the compradors were able to wrest control of China's import trade (Osterhammel, 1999a: 161-2; Feuerwerker, 1983: 195; McKenzie, 1954: 70). Indeed, Wang (1993) has argued that the profitability of AngloChinese trade turned decisively in favour of the latter after 1870. Against this 
background, it is not surprising to learn that Jardine, Matheson gave up many of their direct trading activities during the 1870s and turned instead to the provision of financial and shipping services (LeFevour, 1968: 52-62), whilst Butterfield and Swire recorded losses on their trading activities throughout most of the final three decades of the nineteenth century before they, too, abandoned it in 1902 (Marriner and Hyde, 1967). By the 1920s, Chinese-run import-export companies had completely replaced the comprador-western commission trader as the conduit for China's international trade (Dernberger, 1975: 42).

Upcountry purchasing was one of a range of intermediating functions that the western trading houses relied upon their compradors to perform. Beginning from their role of house steward, Hao (1970) has identified a variety of ways in which compradors assisted the agency houses with their core business transactions. Of particular importance was their role as financial guarantors whenever Chinese firms wished to purchase imported goods by means of a money order against a native bank. From this beginning compradors developed a range of financial services that they performed on behalf of their western employers, including acting as a treasurer's department for the agency houses, guaranteeing payments that the houses made on account, and engaging in a variety of exchange transactions. The financial links that compradors established with native banks were exploited from the 1870s in particular by the western banking houses, such as the Hongkong and Shanghai Bank, in order to provide short term 'chop loans' to small scale Chinese banks (qianzhuang) operating within the Treaty Port economies, whose creditworthiness was guaranteed by the compradors who acted as intermediaries (McElderry, 1976; Smith, 1983; Jones, 1992). 
This role of financial intermediation performed by the compradors of the western banking houses allowed the small scale native banks access to a far greater volume of circulating capital and enabled some of them to subsequently finance indigenous industrial enterprises (Bergère, 1986: 39). Indeed, after 1870 these compradors, as a group, displayed a much greater propensity than other Chinese merchants to pioneer modern industrial enterprises in conjunction with the reforms of the self-strengthening period (Chan, 1977: 8) and many of them also became financially involved in foreign business enterprises during the latter years of the nineteenth century (Osterhammel, 1989: 192; Wang, 1965).

The economic influence of compradors in nineteenth century China expanded in line with the range of functions that they performed. As well as acting as house steward, providing financial services and guarantees, and engaging in upcountry purchasing, compradors also acted as interpreters, provided market intelligence, procured customers and liaised with the Chinese authorities to which they were often closely connected. Indeed, the value of a comprador was directly linked to his political influence and social standing (Hao, 1970: 25-32). This multitude of activities has tended to make an economic analysis of the comprador as an intermediary problematic, particularly because the label 'comprador' has often been attached to a particular individual businessman even when the nature of his relationship to the foreign firm has altered over time from employee to independent commission agent. In order to consider the changing nature of Sino-foreign business relationships, therefore, it is first necessary to consider the comprador as an economic institution. 


\section{The Comprador and Institutional Change in China}

Hao's (1970) study provides various insights into the institutional status of the comprador. First, in identifying the "mechanism of the institution" Hao considers the physical set-up of the comprador's office (its location within the agency house building) and the typical composition of the staff that made it up. In this respect, the institution of the comprador can be viewed as an aspect of the western firms themselves (the "firm within the firm") as they adapted their organisations to the circumstances of Treaty Port China. However, the office of the comprador provided only the institutional setting from which the role developed, rather than representing the institution itself. Second, he considers the qualities that were normally required in a comprador, such as an adequate command of a foreign language and appropriate social standing, which helped to characterise them as a social group within China. Convenient as this socio-economic label may be in understanding why certain groups within China operated effectively as intermediaries, it provides little help in elucidating the specific nature of the economic linkage that bound the comprador to his foreign principal. Third, Hao identifies two aspects of Chinese business practice that helped to define the comprador as an economic institution, namely (i) the guarantee system under which losses incurred were indemnified by the comprador, and (ii) the system of kinship and place of origin connections which created trust-based networks and simplified the process of succession. However, although these two aspects of Chinese business practice were incorporated into the institution of the comprador, they operated more broadly in the Chinese economy and were not institutional characteristics of the comprador system per se. 
As a business institution, the comprador needs to be defined in relation to the firm for whom he operated, and of whom he was necessarily an employee. As an employee whose primary function was intermediation, however, much of the value to be gained from employing a comprador resided in his knowledge of and access to the commercial networks of the native Chinese economy. In practice this meant that, in order to perform successfully, the comprador needed to operate with a degree of latitude which made his actual position more in the nature of an agent than a managed employee. Although firms attempted to draw up contracts of employment that took this into account, by providing remuneration based on both a fixed salary and commission, certain monitoring problems that were inherent in the employment of compradors were effectively impossible to control through contractual stipulation. Many comprador contracts, for example, seem to have contained provisions explicitly precluding (unless expressly agreed) business done on own account. However, since the compradors who were most productive tended to be precisely those with established business interests and connections, such contractual provisions were both difficult to enforce and potentially counter-productive. This system of personal guarantee by the comprador for his principal's business further blurred the employer/employee relationship and enhanced the risks of the comprador (Chan, 1999). Moreover, the informal mechanism of interlocking guarantees that served to protect western firms from bankruptcy on behalf of their compradors were powerless to prevent the same employees from indulging in embezzlement and squeeze.

For the western firms who sought to use compradors as intermediaries, the control over vital sources of information that these employees held placed them, and not their foreign employers, in the pivotal position. Thus, although compradors 
continued to be employed by western firms well into the twentieth century, their role as intermediators diminished rapidly after around 1890 . This was partly because, as the economies of the Treaty Ports (notably Shanghai) expanded, many western business enterprises were content to limit their activities to these enclaves (see e.g. Bickers (1999) for British firms). In addition, the years around the turn of the century witnessed an important programme of institutional reform in China which changed radically the environment that foreign businesses faced. The western banks, for example, responded to the financial reforms put in place by the Qing government after 1900 that established modern-style Chinese banks, by refocusing their lending towards government agencies and industrial concerns (McElderry, 1995: 38), even though in the financial sphere intermediation through compradors did endure (Smith, 1983; Zhongguo renmin yinhang jinrong yanjiusuo, 1990: 685-91). Elsewhere in the Chinese economy, however, insofar as western firms continued to employ compradors it was primarily in the managerial capacity of house steward rather than in the more problematic area of trade intermediator.

By the 1890s therefore, as Hao (1970: 11-12) himself points out, the comprador had become less of a bridge linking foreign businesses to the Chinese economy and more of a barrier that served to pin these enterprises securely into the Treaty Port enclaves where their political influence dominated. Nevertheless, the institutional changes and reforms that were unfolding within China around this time served to encourage foreign firms, especially the emerging group of modern multinational enterprises, to engage in a renewed effort at penetrating the China economy that lay beyond the Treaty Ports. Foremost amongst these changes was the concession granted to the foreign powers by the Qing government, under the terms of 
the Treaty of Shimonoseki in 1895 , to allow direct investment in productive capacity within the Chinese economy. Defeat in the Sino-Japanese War, and later the Boxer Uprising in 1900, had forced the Imperial regime to urgently address the need for modernisation, and the concessions allowed the foreign powers to make investments in mining and, crucially, railways which promised to open up China's vast hinterland to economic penetration. Supported by the spread of the missionary movement and the expansion of the foreign consular service, the efforts at economic modernisation which included currency reforms, the development of modern financial institutions and company laws - provided foreign investors and industrial concerns with a genuine belief that the barriers to marketing their products within China could now be breached.

Few organisations who abandoned the use of compradors in their Chinese distribution systems after 1895 did so with more alacrity than the Japanese Mitsui Bussan trading company. During the early twentieth century this organisation was able to gain a large share of the market for textiles within China (especially in Manchuria) by training their own staff in Chinese language skills and using them to directly replace indigenous compradors (Cochran, 1989). A number of western firms also used the changed conditions around the turn of the century to organise their distribution systems without recourse to the traditional employee/agent form of comprador to support them. In Britain, the leading industrial firms who dominated the China Association interest group based in London, such as ICI (China), the Asiatic Petroleum Co. and BAT (China), saw opportunities to develop the market for their products across the Chinese market using more modern systems of management (Endicott, 1975: 30). ICI began direct marketing of their products within China during 1900 by 
recruiting E.S. Little, who had arrived in China in fourteen years earlier as a missionary. Little's intimate knowledge of Chinese language and custom enabled him to embark on the process of creating a distribution network for ICI in China without the use of compradors by dealing directly with Chinese merchants (Brodie, 1990: 40). Other British firms seeking to expand their sales in China also attempted to avoid their earlier compatriots' dependence on the comprador, as the examples of BAT and KMA will serve to illustrate.

\section{Economic intermediation within BAT}

For BAT, the key to success in China lay in gaining access to and control over indigenous distribution networks through which its products could be supplied to large sections of the Chinese market. In pursuing this objective, the role played by compradors constituted merely a step towards the formation of new forms of economic intermediation.

In relation to the conventional role of the comprador - as exemplified by the comprador's office in the agency houses - BAT's main headquarters in Shanghai still employed a head comprador as late as 1923 . Contemporary documents confirm that Mr Tsai Fou Ling acted as the firm's comprador just as his father and grandfather had done before him for BAT's predecessors, the trading firm of Mustard \& Co. Another long-standing member of the comprador's office had held his position there for 27 years (Ying Mei, 1923).

However, the principal function performed on behalf of BAT by the group of employees that have been designated as compradors (Cochran, 1980: 28-32) was that 
of interpreter, since this was the facility that the company required in order to gain access to the indigenous Chinese mercantile networks. These interpreters were teamed up with western salesman and used as the vanguard in a marketing effort that, by the end of the first decade of the twentieth century, had made inroads for BAT's cigarettes into large swathes of the Chinese economy. The most influential of BAT's interpreter/compradors was Wu Ting Seng, son of a Baptist Minister who was introduced to James Thomas of BAT by an American missionary (Wright, 1908: 544; Wu Sing Pang, 1988: 10-13). Wu and Thomas worked closely together during the years around the turn of the century, and $\mathrm{Wu}$ was instrumental in engineering BAT's effective control of the Shanghai Tobacco Guild (Wright, 1908: 662). In the past, the guilds had operated more as barriers to Western merchants than as facilitators, but $\mathrm{Wu}$ was able to persuade a group of leading Shanghai tobacco firms to work in concert and distribute cigarettes exclusively for BAT who, for their part, funded the provision of facilities for the guild (BAT Papers: 10-E-1/6).

In further developing BAT's network of dealers in China, Thomas utilised the interlocking guarantee tradition on which the comprador system was based in order to recruit Chinese merchants into the company's service. Before being accredited as an “Association Dealer", merchants were required by BAT to demonstrate that they possessed suitable premises and adequate capital resources, but in addition they also needed the support of two other merchants to act as guarantors. Furthermore, before receiving cigarettes on consignment (i.e. credit terms) these distributors were obliged to sign an agreement (called a 16A Agreement) with BAT covering the value of the goods they would be carrying (Cox, 1997: 44-5). Hence the company attempted to 
reinforce the traditional place of origin networks, based on loyalty, with contractual obligations.

Thus the company created a dealership network based on Chinese merchants as secure but independent agents, whilst integrating directly into their organisation as employees a number of Chinese with a western education. Many members of staff who were initially hired in the capacity of interpreters, for example, were subsequently upgraded to act as middle managers in parallel with junior western-recruited or other non-Chinese employees. To label these employees as compradors however, as in the earlier, semi-autonomous, employee/agent sense of the term, must be seen either as strictly inaccurate or ideologically inspired, for these employees were securely embraced within BAT's hierarchical corporate structure.

Notwithstanding the success of this strategy to distribute their products in China avoiding the use of traditional compradors, BAT's ability to enlist Chinese merchants was ultimately constrained by the requirements of capital resources and guarantees. By far the most effective way in which the company could further expand its Chinese distribution system, therefore, was by allowing the largest merchants greater scope for using their own networks of associated dealers, in which common place of origin loyalties could facilitate an enormous reduction in the transactions costs of doing business.

In 1911 BAT attempted to create a mechanism through which such an arrangement could be utilised. Setting up a fully owned subsidiary company in London to own certain of their cigarette brands, BAT then floated another company in China called the Union Trading Company which was granted the rights to sell these brands in the Chinese market. Shares in the Union company were owned $51 \%$ by BAT and $49 \%$ 
by its former comprador Wu Ting Seng. The objective was to create an institutional framework in which a less restrictive system of distribution could be developed, featuring the more generous credit terms that operated within indigenous trading networks, but over which BAT could retain executive control (Cox, 2000: 154). In so doing, the institutional status of $\mathrm{Wu}$ was thus shifted from employee/agent to joint venture partner.

The experiment continued for around six years, but although it boosted sales the operation ran into financial difficulties and was wound up by Thomas' successor in Shanghai, Thomas Cobbs, in 1919. The problems experienced with the Union initiative, however, lay not in any deficiency with the corporate structure that had been employed, but in the fact that Wu lacked sufficient strength of contacts upon which Chinese place of origin networks were essentially founded. Thus as the Union experiment began to founder, BAT's managers sought an alternative enterprise through which to develop the scheme. This they found in the shape of a merchant/entrepreneur called Cheang Park Chew and his firm the Wing T'ai Vo Tobacco Company. The Wing T'ai Vo organisation had been developed around a group of Cantonese merchants and, as founder members of the Shanghai Tobacco Guild, the firm had been particularly successful in building up sales of the "Ruby Queen" brand of cigarettes (Chen Ren Jie, 1978). When, in 1912, BAT granted his firm an exclusive franchise to sell the "Ruby Queen" brand across the entire Chinese market (rather than merely within the Shanghai district) Cheang had taken advantage of the new Chinese corporate laws to register Wing T'ai Vo as a limited company. Five years later this arrangement with Wing T'ai Vo was put on a stronger footing when BAT assumed responsibility for all the Chinese firm's distribution costs and 
changed the terms of its arrangement with the company to a commission-only basis (Thomas Papers: Contract between BAT (China) and Cheang Park Chew, 16 May 1919).

These moves were a prelude to the formation, in 1921, of the Wing T'ai Vo Tobacco Corporation, another joint venture owned $51 \%$ by BAT. In contrast to the earlier arrangements, the joint venture status of Wing T'ai Vo allowed BAT to have direct control over the financial management of the subsidiary, whose accounting system was fully integrated into that of the parent company. Indeed, the new Wing T'ai Vo operation was constructed along exactly parallel lines to that of the parent company but with staffing costs that were a fraction of those borne by BAT with its highly paid Western employees. By 1923, the Wing T'ai Vo operation was responsible for over one third of BAT's China-wide cigarette sales (by number) (Shanghai, 1983: $630)$.

The Wing T'ai Vo Tobacco Corporation thus provides another example of a Chinese firm operating within a Western firm, but one that was embedded far more securely into the management structure of the parent company than the earlier examples provided by the employee/agent compradors. Like many of the earlier compradors, the main Chinese protagonist of Wing T'ai Vo, Cheang Park Chew, became extremely wealthy, but in his case it was decidedly not at the expense of the western firm with whom he collaborated. 
$\underline{\text { KMA's economic intermediation }}$

Although KMA also adopted a joint venture approach similar to that used by BAT in order to extend control over its former comprador, the KMA authorities did not aim at simply extending its distribution market through this joint venture. Instead, it wanted to extend its control and command over the existing networks and to gain further access to the indigenous market. In this respect, the joint venture approach provided an effective forum for KMA to monitor and to constrain the activities of the dealers and its former comprador.

As the product of an amalgamation agreement between the British controlled Chinese Engineering and Mining Company Ltd. (CEMC) and the Chinese-owned Lanchow Mining Company in 1912, the Kailan Mining Administration was effectively under British domination in management (Wright, 1984: 123; Carlson, 1957: 54-113, 137-139; Wei, 1954: 152-155, 159-162). Having originally taken over the Kaiping Mines from its Chinese founders in 1900, the CEMC expanded production by modernising the mines' equipment, plants and other capital investments, including railway, coal-carrying fleet and new shafts (Carlson, 1957: 81). After the amalgamation, the new management continued to invest substantially in fixed capital (Gu, 1916: 29-69). In production, both Kaiping and Lanchow Mines expanded drastically under the British managerial domination (Carlson, 1957: 114, 146; Zhang, 1992: 139).

To distribute coal beyond North China, the British management of KMA placed agencies in major markets, including Shanghai. The Shanghai agency had been introduced before the amalgamation by the CEMC (Carlson, 1957: 73) and placed 
under the control of a westerner who employed a Chinese comprador to promote business among the Chinese community, particularly among the dealers who had been controlling distribution to the final consumers. After the formation of KMA, this distribution structure remained intact (Liu Hongsheng: 200). Under this system the KMA's comprador in Shanghai, Liu Hongsheng, retained many of the conventional features of the employee/agent comprador. He was responsible for collecting market information, for translating Chinese correspondence from the customers, for bringing Chinese customers to his principal and for guaranteeing the transactions of KMA with the Chinese customers, particularly dealers who handled coal distribution. To handle all these administrative responsibilities, Liu also had his "comprador office" within the same compound of KMA's Shanghai Agent. (Chan, 1998: 82-88, 100-101).

Under Liu Hongsheng's compradorship, the sales of Kailan coal in Shanghai increased substantially. The market share of Kailan coal in Shanghai increased from around 15 per cent in 1912 to more than 50 per cent in 1920. Although it dropped slightly in the early 1920s, Kailan coal continued to hold the lion's share of the Shanghai market before 1925 (Liu Hongji: 07-011; Zhang, 1992: 139). Such an expansion was not only a result of the urbanisation and industrialisation of Shanghai and the Lower Yangzi region but also Liu's efforts by building up a region-wide distribution network.

By using the distribution networks of a major Shanghai coal dealer, Nee Tai Shing Coal Merchant, Liu Hongsheng managed to extend the sales of Kailan coal to new markets such as Suzhou, Wuxi, Changshu, Hangzhou, Huzhou, Pinghu and Qingpu (Liu Hongji: 06-014, 06-015). In the early 1920s, Liu also enabled KMA's Shanghai agency to extend its distribution networks to some of these and other 
markets, including Nanjing, Nantong, Changxing, Changzhou, Hengli and Jiujiang. In these markets, local coal dealers other than the Nee Tai Shing networks were given regional or sub-regional distribution contracts. By 1924, the number of these other coal dealers had risen to seventeen (Chan, 1999).

As an intermediator, Liu Hongsheng stood between the KMA's Shanghai Agent and these coal dealers acting not only as a business assistant to the former but also a guarantor of the dealers. To reduce his risks under the guarantee system, and to earn profits from both ends of the trade, Liu invested directly in many of these coal dealers behind the KMA's back. Before 1925, the number of coal dealing partnerships that Liu invested amounted to five (Liu Hongji: 12-001, 12-008). These coal dealers either directly contracted coal from the Shanghai Agent, or teamed up with other dealers to trade with KMA. In addition, Liu Hongsheng formed partnerships with Nee Tai Shing in some of these dealerships and wharves enabling him to obtain insider knowledge (Liu Hongji: 06-015, Calder to Lieu, 14 March 1924; 12-001; Chan, 1998: 45-51).

This distribution network of coal dealers developed by Liu Hongsheng contributed substantially to the growth of sales in KMA, but at the same time created serious problems for the foreign enterprise. To the KMA, the coal dealers were instrumental in providing the know-how to open up new markets, but they also acted as obstacles for direct marketing to the final customers (Nathan Papers, 425: Nathan to Turner, 3 April 1933). Moreover, the contractual terms between KMA and the dealers did not impose effective control and discipline over the latter, particularly on the issue of defection and sub-contracting, which presented problems to KMA's regional pricing policy. In the face of intensified market competition during the early 1920 s, from both 
Japanese sources and other Chinese coal producers, it became imperative for KMA to implement certain marketing reforms (Chan, 1999).

Early in 1923, therefore, the KMA's Shanghai Agent set up the "Chinese Native Sales" department under the direct command of a British employee who knew some Chinese. This British employee of the Shanghai Agent made personal visits to markets, and inspected the books of some Chinese coal dealers, thus gaining a deeper understanding of Liu Hongsheng's involvement in coal distribution (Chan, 1998: 102106). Nevertheless, the outcome of KMA's marketing reforms was not intended to replace Liu Hongsheng and the Chinese dealers. Instead, a new institutional framework was launched in which all the parties concerned, including Liu and the dealers, would participate in a partnership with KMA. Negotiations took place in April 1924 and a partnership agreement between Liu Hongsheng and KMA was finally reached in June 1924 (Liu Hongji: 14-047). The main focus of this partnership agreement was to form a Kailan Sales Agency designed to commence its operations from January 1925. In this partnership, KMA held 50 per cent of the shares, and Liu Hongsheng and Nee Tai Shing equally held the remaining 50 per cent. Nee Tai Shing agreed to hand over its Kailan coal distribution business to this new agency and to transfer members of its staff as required by Liu Hongsheng to KSA. Meanwhile, Liu Hongsheng formed a partnership with Nee Tai Shing within this new agency, with Liu Hongsheng as Nee Tai Shing's representative (Liu Hongji: 06-002). Liu agreed to form this agreement in return for a promise by the KMA to take over the bad debts of his coal distribution business, to guarantee him a basic level of profit for Liu, and to negotiate for the purchase of the wharves in Shanghai that he owned (Chan, 1998: 109-110). 
Under this new institutional setting, KSA was directly incorporated into the KMA establishment with one half of KSA's issued capital (and assets) owned by KMA. The new sales agency did not possess bargaining power with KMA over the question of pricing but was obliged to accept a basic price annually set by the parent company. Nor did it possess the power to decide the quantity of coal to be allotted. Its accounting procedures were set down by the KMA's management, bringing its financial structure still more closely into line with that of the KMA than had been the case earlier. In addition, Liu Hongsheng was discharged of his financial responsibility to guarantee the dealers (Chan, 1998: 111-113, 129).

This joint venture formula was gradually extended across the whole distribution network formerly operated through the dealers. Throughout the late 1920s, KMA saw some of the formerly independent coal dealers become KSA agents, and Liu set up coal dealing partnerships which styled themselves as 'KSA Agent' but which actually functioned like branches. Under the second partnership agreement with Liu in 1928, KSA took over some of the shares of these latter dealers which they incorporated as limited liability companies (Shanghai, 1981: vol 1: 19, 29-30; Liu Hongji: 06-017). Through this process of corporate consolidation, therefore, KMA was able to use the KSA venture to extend the the parent/subsidiary structure of control over its entire distribution network in the Lower Yangzi region.

The KSA joint venture also enabled KMA to acquire more knowledge about Liu's activities in coal distribution and to monitor his activities within the new institutional framework. When KMA encountered further difficulties resulting from Liu's direct involvement with the dealers, it took a series of measures against him, including administrative and legal actions throughout 1933-1935, before finally 
dissolving the KSA in 1939 upon the expiration of the second agreement (Chan, 1998: 131-135).

\section{Conclusion}

Between the events of 1842 and the overthrow of the Qing dynasty in 1911, the prevailing circumstances that faced foreign business enterprises within China underwent profound changes. At the time of the Treaty of Nanjing, western trading houses faced almost insurmountable obstacles in their attempts to establish closer links within the Chinese economy. Largely ignorant of indigenous business conditions and customs, these western organisations desperately needed the services of a commercial go-between in order to advance their business in China. A little over half a century later, the bulk of China's import and export trade had fallen under the control of Chinese business networks with whom the compradors of foreign firms had earlier traded, whilst many of the Chinese intermediaries who had been employed by the trading houses had established independent enterprises. Thus by the beginning of the twentieth century British importers in Shanghai, Hong Kong and Tientsin, for example, had been reduced to the status of commission agents of the Chinese cotton guilds (Osterhammel, 1999a: 161).

The signing of the Treaty of Shimonoseki in 1895, at the conclusion of the Sino Japanese war, can effectively be seen as the starting point of a new era of Sino western business relationships. From this point, the age of trade-led foreign involvement began to give way a era of direct investment, and the importance of the traditional form of economic intermediation, based on the institution of the comprador, fell increasingly 
into abeyance. This process was given further economic impetus by the institutional changes and reforms that followed the Boxer Rebellion in the early twentieth century, whilst the political fate of the comprador was effectively sealed by the onset of the Republican revolution in 1911.

In their efforts to expand business in China, foreign traders operating in the second half of the nineteenth century faced a fundamental dilemma that is well captured by the institutional framework of the principal/agent model. Compradors were hired by these firms to perform a range of tasks, some of which were primarily managerial (hiring and supervising Chinese staff), others of which were essentially entrepreneurial (undertaking and guaranteeing business transactions). Arranging a system of incentives and monitoring procedures that could deal effectively with this diversity of activities proved to be well-nigh impossible given the prevailing institutional conditions of nineteenth century China.

Under these circumstances, the defining relationship between the foreign firm and its comprador was that of employer and employee. However, much of the value to be gained from hiring the services of a comprador depended upon providing these intermediaries with a degree of latitude in their dealings with Chinese merchants. This predisposition towards entrepreneurship and risk-taking on behalf of compradors meant that a simple wage contract was an inappropriate method of reward. In fact, those compradors who acted effectively as agents, rather than solely as employees, of foreign firms bore two kinds of risk when they engaged in transactions on behalf of their principals. First, since compradors invariably transacted with Chinese merchants whose integrity they could trust, they were willing to guarantee these transactions for their principals. Thus the remuneration for this service paid by the foreign firm to their 
comprador can be seen as the payment of a simple insurance premium. However, the second type of risk borne by the comprador was that based on the normal uncertainty of business which both the comprador and foreign firm faced equally. In this respect either a fixed wage or a commission would prove to be an inadequate reward. The incentive for these compradors was to break out of the employer/employee relationship altogether as soon as they had (i) enough capital to make purchases directly and (ii) had built up the necessary contacts with commission merchants. Where the comprador and his foreign employer had built up long term mutual trust, it frequently became advantageous to both of the parties for the employment contract to be curtailed and for the relationship to become one of arms'-length personal exchange, minimising transactions costs. Thus Hao (1970: 37-9) points out that some of the most successful arrangements for managing economic transactions during the latter part of the nineteenth century were based upon relational contracts between foreign firms and their ex-compradors.

More intractable than the reward structure was the issue of asymmetric information and systems of monitoring. Whenever compradors engaged in transactions on behalf of their principals - for example in up-country purchasing - the foreign firm was primarily reliant upon the comprador to provide it with business intelligence. In the absence of an effective system of monitoring, foreign firms were placed in a position of weakness which compradors exploited to their own advantage. Contractual provisions designed to prevent deviant behaviour on behalf of compradors, such as clauses that prohibited embezzlement (e.g. Smith, 1983: 94), were extremely difficult to enforce. 
It is therefore relatively easy to understand why foreign firms found the use of compradors increasingly problematic. By the turn of the century, the role of the archetypal employee/agent comprador as trade emissary had fallen largely into abeyance. However, the institutional changes that were promulgated in China during the late Qing and early Republican period allowed a new group of foreign firms investing within China to exploit the domestic market - to develop new forms of relationships with Chinese business enterprises. The introduction of company law enabled foreign firms to set up their own subsidiary enterprises in China which were effectively Chinese-run enterprises. In adopting such an approach, British-run firms such as BAT (through its Union and Wing T'ai Vo subsidiaries) and KMA (through its Kailan Sales Agency) were able to create a framework through which the role of intermediation could operate more securely. These parent/subsidiary arrangements allowed the foreign firm to solve the earlier principal/agent problems by providing both common incentives through joint profit maximisation and an effective (or at least more effective) monitoring system via an integrated accounting system and the appointment of a western supervisor to oversee the subsidiary. Thus many of the intermediation functions performed earlier by compradors could be retained, but within an institutional structure that placed more emphasis on partnership between the two parties.

The introduction of more advanced corporate structures by foreign businesses within China became increasingly common during the Republican era for a variety of reasons. In the early 1920 s, western firms such as Brunner, Mond (a forerunner to ICI) were given encouragement by the British Commercial Attaché in Peking to transfer their management in China to a local board of directors and to seek closer cooperation with the Chinese (Reader, 1970: 336-7), whilst following the establishment 
of the regime in Nanjing foreign firms looked increasingly towards joint ownership arrangements to stave off Nationalist resentment and pressure (Osterhammel, 1984: 274-6). However, these initiatives were driven primarily by the need to accommodate Chinese demands for greater direct involvement in domestic industrial enterprises and were thus politically driven. From an economic perspective, the creation of joint ventures in the form of parent/subsidiary relations developed by BAT and KMA was designed to gain greater access to the indigenous business networks that foreign firms needed in order to distribute their products widely within China. Thus the creation of Sino-foreign joint ventures in the Republican era was not motivated simply by political considerations.

As Bickers (1999: 182-95) has recently pointed out, as well as creating joint ventures with Chinese firms, British companies also integrated more Chinese employees directly into their management structures. Such a policy helped to modernise foreign businesses in China and overcame the social stigma that Chinese employees had suffered during the comprador era. However, this strategy of localisation was common to multinational enterprises in many parts of the world, in Latin America and Europe for example, during the upsurge of nationalism and cartelisation that followed the trade depression of the early 1930s (Jones, 1996: 44-5). What made the Chinese case special was not localisation per se, but the fact that foreign businesses in China were constrained by the Treaty Port system and extraterritoriality to operate at arms' length to most of the Chinese hinterland. To achieve success in mass marketing, therefore, these firms needed to gain access to distribution systems that lay beyond their direct reach. Whilst the institution of the comprador, based on the employee/agent contractual form, had proved to be an 
unsustainable mechanism of intermediation, what firms such as BAT and KMA began

to appreciate after the Republican revolution was that joint ventures structured around parent/subsidiary companies gave them the means to facilitate far more robust forms of Sino-foreign business relationship.

$\underline{\text { References }}$

BAT Papers, Centre for Chinese Business History, Shanghai Academy of Social Sciences.

Bergère, M.C. (1986), The Golden Age of the Chinese Bourgeoisie, 1911-1937. Cambridge: Cambridge University Press.

Bickers, R. (1999), Britain in China: Community, Culture and Colonialism 19001949, Manchester: Manchester University Press.

Brodie, P. (1990), Crescent Over Cathay: China and ICI, 1898 to 1956, Oxford, Oxford University Press.

Cain, P.J. and A.G. Hopkins (1993), British Imperialism: Innovation and Expansion, 1688-1914. London: Longman.

Carlson, E.C. (1957), The Kaiping Mines (1877-1912), Cambridge MA: Chinese Economic and Political Studies, Harvard University.

Chan, Kai Yiu (1998), The Structure of Chinese Business in Republican China: the Case of Liu Hongsheng and his Enterprises, D. Phil. Thesis, University of Oxford.

- (1999), 'A turning point in China's comprador system: KMA's changing marketing structure in the Lower Yangzi region', Paper presented at the Association of Business Historians' Annual Conference, Centre for International Business Studies, South Bank University, London, 2-3 September.

Chan, W.K.K. (1977), Merchants, Mandarins and Modern Enterprise in Late Ch'ing China. Cambridge, MA: Harvard University Press.

Chen, Ren Jie (1978), 'Ying Mei yan gong si mai ban Zhen Bo Zhao' [The comprador of the BAT Co.: Cheang Park Chew], Wenshi ziliao xuanji [Selection of material relating to culture and history], Shanghai: Zhong guo renmin zhengzhi xieshang huiyi [Consultative Political Conference of the Chinese People].

Cochran, S. (1980), Big Business in China: Sino-Foreign Rivalry in the Cigarette Industry, 1890-1930. Cambridge, MA: Harvard University Press.

- (1989), 'Japan's Capture of China's Market for Imported Cotton Textiles before World War I: The Role of Mitsui Trading Company', The Second Conference on Modern Chinese Economic History. Taipei: Academia Sinica.

Cox, H. (1997), 'Learning to do Business in China: The Evolution of BAT's Cigarette Distribution Network, 1902-41', Business History, Vol.39, No.3, pp.30-64. 
- (2000), The Global Cigarette: Origins and Evolution of British American Tobacco, 1880-1945. Oxford: Oxford University Press.

Dernberger, R.F. (1975), 'The Role of the Foreigner in China's Economic Development, 1840-1949', in D.H. Perkins (ed.), China's Modern Economy in Historical Perspective. Stanford, CA: Stanford University Press.

Endicott, S.L. (1975), Diplomacy and Enterprise: British China Policy, 1933-1937. British Columbia: University of British Columbia Press.

Fairbank, J.K. (1992), China: A New History. Cambridge, MA: The Belknapp Press of Harvard University Press.

Feuerwerker, A. (1983), "The Foreign Presence in China”, in J.K. Fairbank, The Cambridge History of China, Vol 12: Republican China 1912-1949, Part 1, Cambridge: Cambridge University Press, pp.128-207.

Gu, Lang (comp.) (1916), Zhongguo shida kuangchang ji [A survey record of the largest ten mines in China], Shanghai: The Commercial Press.

Hao, Yen-p'ing (1970), The Comprador in Nineteenth Century China: Bridge Between East and West. Cambridge, MA: Harvard University Press.

Jones, G. (1992), British Multinational Banking, 1830-1900. Oxford: Oxford University Press.

- (1996), The Evolution of International Business: An Introduction, London, Routledge.

Kirby, W.C. (1995), "China Unincorporated: Company Law and Business Enterprise in Twentieth Century China”, Journal of Asian Studies, Vol. 54, No.1, pp. 43-63.

LeFevour, E. (1968), Western Enterprise in Late Ch'ing China: A Selective Survey of Jardine, Matheson and Company's Operations, 1842-1895. Cambridge, MA: Harvard University Press.

Liu Hongji Zhangfang Dang'an [Archives of Lieu Ong Kee Accounts Office] Resource Centre for Chinese Business History, Shanghai Academy of Social Sciences.

Liu Hongsheng qiye fangwenlu, da shi ji [Interview records, chronicle of the enterprises of Liu Hongsheng], in Liu Hongsheng Qiyi Ziliao [Materials of the enterprises of Liu Hongsheng], Shanghai Academy of Social Sciences.

Mackenzie, C. (1954), Realms of Silver: One Hundred Years of Banking in the East. London: Routledge \& Kegan Paul.

Marriner, S. and R.E. Hyde (1967), The Senior: John Samuel Swire, 1825-1898. Liverpool:

McElderry, A.L. (1976), Shanghai Old Style Banks (Ch'ien-chuang), 1800-1935. Ann Arbor: University of Michigan Centre for Chinese Studies.

- (1995), 'Securing Trust and Stability: Chinese Finance in the Late Nineteenth Century', in R.A. Brown (ed.), Chinese Business Enterprise in Asia. London: Routledge, pp. 27-44.

Nathan Papers, Bodleian Library, University of Oxford.

Negishi, Tadashi, (1948) Baiben seido no kenky @ [A study of the comprador system] Tokyo.

Osterhammel, J. (1984), 'Imperialism in Transition: British Business and the Chinese Authorities, 1931-37', China Quarterly, No. 98, pp. 260-86.

- (1989), 'British Business in China, 1860s-1950s', in R.P.T. Davenport-Hines and G. Jones (eds.), British Business in Asia since 1860, Cambridge: Cambridge University Press, pp. 189-216. 
- (1999a), 'Britain and China, 1842-1914', in A. Porter (ed.), The Oxford History of the British Empire: The Nineteenth Century: Oxford: Oxford University Press, pp. 146-69.

- (1999b), 'China', in J.M. Brown and W.M.R. Louis (eds.), The Oxford History of the British Empire: The Twentieth Century: Oxford: Oxford University Press, pp. 643-66.

Reader, W.J. (1970), Imperial Chemical Industries: A History, Volume 1, London, Oxford University Press.

Shanghai shehui kexueyuan jingji yanjiusuo (comp.) (1981), [Economic Research Institute at the Shanghai Academy of Social Sciences], Liu Hongsheng Qiye Shiliao [Sources of the history of Liu Hongsheng's enterprises], 3 vols. Shanghai: Shanghai renmin chubanshe.

- (comp.) (1983), Ying Mei Yan Gongsi zai Hua qiye ziliao huibian [Documents on the enterprises of BAT in China], 4 vols. Shanghai: Shanghai renmin chubanshe.

Smith, C.T. (1983), “Compradores of the Hongkong Bank”, in F.H.H. King (ed.), Eastern Banking: Essays in the History of the Hongkong and Shanghai Banking Corporation, London: Athlone Press, pp. 93-111.

Thomas Papers, Special Collections Department, William R. Perkins Library, Duke University.

Wang, J.L.S. (1993), 'The Profitability of Anglo-Chinese Trade, 1861-1913', Business History, Vol.35, No.3, pp.39-65.

Wang, Jingyu (1965), 'Shijiu shiji waiguo qinhua qiye zhong de huashang fugu huodong' [Share-affiliation by Chinese merchants in foreign enterprises detrimental to China in the nineteenth century], Lishi yanjiu [Historical research], No.4, reprinted in Huang Yiping (ed.), Zhongguo Jindai Jingjishi Lunwen Xuan [Selected essays on economic history of modern China], Shanghai: Shanghai renmin chubanshe, 1985, pp.193-257.

Wang Shui, (1990) 'Maiban zhidu de yanbian' [The transformation of the comprador system], in Xu Dixin and Wu Chengming (eds.), Zhongguo zibenzhuyi fazhanshi, dierjuan [A history of the development of capitalism in China], Vol. 2. Beijing, pp.754-786.

Wei, Zichu (comp.) (1954), Diguo zhuyi yu Kailuan meikuang [Imperialism and the Kailan Mining Administration], Shanghai: Shenzhou guoguangshe.

Wright, A. (ed.) (1908), Twentieth Century Impressions of Hongkong, Shanghai, and other Treaty Ports of China: Their History, People, Commerce, Industries and Resources, London: Lloyd's Greater Britain Publishing Company.

Wright, T. (1984), Coal Mining in China's Economy and Society, 1895-1937, Cambridge: Cambridge University Press.

Wu, Sing Pang (1988), 'Mr Wu recalls his family's BAT links of pre-war years', BAT News, Spring, London: British American Tobacco Co. Ltd.

Ying Mei Yien Kung Ssu (1923), Yueh Pao [British American Tobacco Company Monthly Journal], September, Shanghai: BAT (China) Ltd.

Zhang, Guohui (1992), 'Cong Kailuan meikuang lianying kan jindai meikuangye fazhan zhuangkuang' [From the joint sales of the Kailan Mining Administration to see the development conditions of modern mining industry], Lishi yanjiu, no.4, pp.137-53. 
Zhongguo renmin yinhang jinrong yanjiusuo [Financial Research Institute, People's Bank of China] (comp.)(1990), Meiguo Huaqi Yinhang zai Hua shiliao [Historical Sources on the City Bank of New York in China], Beijing, Zhongguo jinrong chubanshe. 